\title{
The Improvement Of Student Learning Outcomes At SMKN 5 Jember
}

\author{
Yayuk Widhyawati ${ }^{*}$, Muhammad Dimyati², Hary Sulaksono ${ }^{3}$ \\ 1,2,3 High School Of Economic Science (Stie) Mandala Jember
}

\section{A R T I C L E I N F O}

Article history:

Received 19 August 2018

Received in revised form

16 September 2018

Accepted 15 October 2018

Available online 26

November 2018

Keywords:

Student Learning Outcomes,

Learning Environment,

Teacher Competence,

Learning Methods, Student

Absorption.

\begin{abstract}
A B S T R A C T
The quality of education in a school, one of which can be seen from the learning outcomes of its students. Student learning outcomes at SMKN 5 Jember can be measured from four factors, such as: learning environment, teacher competency, learning method and student absorption in receiving lessons. Based on the explanation above, the formulation of the problem in this study is how is the influence of the learning environment, teacher competency, learning methods and student absorption in receiving lessons on student learning outcomes at SMKN 5 Jember. This study aims to examine whether there is an influence of /the learning environment, teacher competence, learning methods and student absorption in receiving lessons on student learning outcomes at SMKN 5 Jember. The population of this study were students of SMKN 5 Jember 2017/2018 academic year. In this study, researchers will use accidental sampling. Accidental sampling is a chance-based sample determination technique, that anyone who happens to meet with a researcher can be used as a sample, if it is seen by someone who happens to be a suitable data source. In this study, researchers took a sample of 30 respondents, because this study uses multiple linear regression analysis SPSS version 16 application. Based on data analysis shows that the learning environment has a significant effect on student learning outcomes at SMKN 5 Jember. Whereas teacher competency, learning method and student absorption in accepting lessons do not give effect to student learning outcomes at SMKN 5 Jember.
\end{abstract}

\footnotetext{
* Corresponding author.

E-mail addresses: yayukwidhyawati@gmail.com (Yayuk Widhyawati)
} 


\section{Introduction}

National Education is a conscious and planned effort to create a learning atmosphere and learning process so that students actively develop their potential to have the spiritual, religious, self-control, habits, intelligence and skills needed for themselves, society, nation and state (Article 1 UU No. 20 of 2003). As one of the institutions that organizes formal education, schools have a very important role in realizing national education goals through learning activities. One of the qualities of education in a school can be seen from the results of student learning, this is what was studied at SMK 5 Jember, if student learning outcomes are good then the quality of school education is good, and vice versa. Student learning outcomes at SMK 5 Jember can be measured from four factors, namely: learning environment, teacher competence, learning methods and absorption of students in receiving lessons. Based on the explanation above, the formulation of the problem in this study is how the influence of the learning environment, teacher competence, learning methods and absorption of students in receiving lessons on student learning outcomes in SMK 5 Jember.

This study aims to examine the presence or absence of the influence of the learning environment, teacher competence, learning methods and absorption of students in receiving lessons on student learning outcomes in SMK 5 Jember. The population of this study is SMKN 5 Jember students in the academic year $2017 / 2018$.

The research of Mustofa Setyo Ariwibowo (2011) with the title "The Effect of Learning Environment on Learning Achievement of PPKn Students of the 2008/2009 of Ahmad Dahlan University Odd Semester Academic Year 2010/2011." States that there was a positive and significant influence between the learning environment PPKn student learning achievement in the year of 2008/2009 amounted to $7.3 \%$ while the remaining $92.7 \%$ was explained by other variables were not analyzed in this study.

Sutadi's research, Sugiharsono (2016) with the title "The Effect of Teacher Competence, Learning Motivation, Family Environment on the Learning Outcomes of Economic Subjects," states that teacher competence gives a positive and significant influence on student learning outcomes partially, there is a unidirectional relationship between teacher competence and student learning outcomes.

The equation with this study is that the variables discussed as dependent variables are student learning outcomes which have the same goal, namely to find out what variables or dimensions influence student learning outcomes. This research uses data collection techniques in the form of questionnaires, observations, interviews. Populations which is used are students. This research uses a quantitative approach. While the differences are different research locations, different number of variables or independent dimensions. The validity testing techniques which is used is multiple linear regression.

From this background, this study aims to examine the effect of the learning environment, teacher competence, learning methods and student absorption in accepting lessons on student learning outcomes in SMK 5 Jember.

\section{Method}

This research was conducted at SMK 5 Jember. SMKN 5 Jember is a State Vocational School located in East Java Province, Jember. School having its address at Jalan Brawijaya 55, Jubung Village, Sokorambi Jember District. Founded on February 14, 1975, and has 12 packages of expertise. The research time is December 2017 - June 2018.

In this study, researchers took a sample of 30 respondents, because this study uses multiple linear regression analysis with the conditions of five (5) observations of the number of variables, namely $5 \times 5$ (variables) $=25$ respondents, then the sample of 30 respondents has represented the number of samples which exists. The population in this study were students of SMK 5 in the academic year 2017/2018. In this study, researchers will use accidental sampling. Accidental sampling is a technique for determining samples based on chance, that is, anyone who accidentally meets with a researcher can be used as a sample, if it is viewed by someone who happens to be a suitable source of data.

This study consists of two (2) types of variables, namely independent variables or variables that do not depend on other variables and dependent variables or dependent variables from other variables. In this study the dependent variable is student learning outcomes. Whereas the independent variables are the learning environment, teacher competence, learning methods and absorption of students in receiving lessons. Operational definitions show indicators that will be used to measure variables in more detail. Operational definitions in this study consist of: (1) learning outcomes with indicators of verbal information, intellectual skills, cognitive strategies, motor skills, attitudes, (2) learning environment with indicators of educational process standards, availability of facilities and infrastructure, teacher and 
employee work culture school, Implementation of school discipline, (3) teacher competence with indicators of pedagogic competence, personality competence, social competence, professional competence, (4) learning methods with skills, knowledge, teaching and learning indicators, using of media, (5) student absorption in accepting lessons with internal and external indicators of students.

Measurement of learning outcomes is a formal effort carried out systematically by the school management in evaluating the results that have been achieved by utilizing resources owned by the school efficiently and effectively in a period to achieve the goals or mission set by the school. The indicator of measuring student learning outcomes are by comparing the realization of work with the target and seen from the element of behavior which consists of aspects of service orientation, integrity, commitment, discipline, cooperation, and leadership.

The method of data collection in this study uses interviews, observation and questionnaires (questionnaires). The data analysis method used in this study are first: Data Validity Test consisting of 1) Validity Test, 2) Reliability Test, second: Classical Assumption Test which consists of 1) Normality Test, 2) Multicollinearity Test, 3) Heteroscedasticity Test, third: Multiple Linear Regression Analysis, fourth: Hypothesis Test consisting of 1) Multiple Determination Coefficient Test (R2 Test), 2) Partial Test (t Test).

\section{Result and Discussion}

The data analysis used in this study is divided into 2 parts, the first is according to statistical descriptions with respondents questionnaires totaling 30 people with a total return of questionnaires is $100 \%$. The second is according to the respondent's description, namely a) The number of respondents' genre that are male by $36.6 \%$, while respondents who are few are female at $63.4 \%$; b) The highest age of respondents is respondents with age 17-18 years that is equal to $70 \%$, while the lowest age of respondents is respondents aged 15-16 years that is equal to 30\%; c) The largest group of respondents from the class XII is $73.3 \%$ and the class $\mathrm{XI}$ is a low respondent which is $26.7 \%$, while the class $\mathrm{X}$ is $0 \%$

By using multiple linear regression analysis the magnitude of the constant (a) is 1.203 which means that the learning outcomes of SMK N 5 Jember students will increase if the work environment variables, teacher competencies, learning methodologies and student absorption are well fulfilled. The magnitude of the regression coefficient of the learning environment variable is positive at 0.868 means that the better the learning environment, the student learning outcomes increase. The magnitude of the regression coefficient teacher competency variable is positive at 0.154 , means that the better the teacher's competency, the student learning outcomes increase. The magnitude of the regression coefficient of the learning method variable is negative at -0.28 , which means that there is a relationship in the opposite direction to student learning outcomes, the student learning outcomes will decline.

The magnitude of the regression coefficient of the student absorption power variable is positive at 0.138 means that the better the absorption of students, the student learning outcomes increase

Based on the results of processing with the SPSS version 16 program, the Multiple Determination Coefficient (R2) test was 0.975 or $97.5 \%$. Thus it can be concluded that $97.5 \%$ that the independent variables include the Work Environment (X1), Teacher Competence (X2), Learning Methodology (X3), Absorption of Students in Receiving Lessons (X4), together (simultaneously) explain (influencing) changes in the dependent variable on Student Learning Outcomes at SMK N 5 Jember (Y) which is $97.5 \%$.

By using the $t$ test, it is found that a) the learning environment variable obtained has learning $t$ count of 4.096 and a significance value of 0.000 . The results of the study obtained a significance value of $0,000<0,05$; this shows that the learning environment has an effect on student learning outcomes in SMK $\mathrm{N} 5$ Jember. Because the learning environment is considered good, it improves student learning outcomes; b) the teacher competency variable is the result of $t$ count of 1.844 . The results of the study obtained a significance value of $0.077>0.05$; This shows that teacher competence does not affect student learning outcomes at SMK N 5 Jember. Because teacher competence is considered low by respondents, it does not improve student learning outcomes at SMK N 5 Jember; c) the learning method variable is the result of $t$ count of -0.241 and the significance value of 0.812 . The results of the study obtained a significance value of $0.812>0.05$; This shows that the learning method does not affect the learning outcomes of students at SMK N 5 Jember. Because the learning method is considered not varied by the respondent, it does not improve student learning outcomes in SMK N 5 Jember; d) the absorptive variables of students in receiving lessons the results of $t$ count are 1.071 and the significance value is 0.294 . The results of the study obtained a significance value of $0.294>0.05$; This shows that the absorption of students in receiving lessons does not affect the learning outcomes of students in SMK N 5 Jember. Because the absorption of students in receiving lessons is considered low, it does not improve student learning outcomes in SMK N 5 Jember. 


\section{Conclusion}

Based on partial data analysis, it was found that the learning environment variables had a significant effect on student learning outcomes at SMK 5 Jember, teacher competency variables, learning methods and student absorption in receiving lessons had no significant effect on student learning outcomes at SMK 5 Jember.

\section{Refrences}

Ariwibowo, Setyo, Mustofa.2011.Pengaruh Lingkungan Belajar Terhadap Mahasiswa PPkn Angkatan 2008/2009 Universitas Ahmad Dahlan Semester Ganjil Tahun Akademik 2010/2011. Yogyakarta: Universitas Ahmad Dahlan.

Hadisi La, Astina Ode Wa, Wampika.2017.Pengaruh Kreativitas Mengajar Guru Terhadap Daya Serap Siswa Di SMK Negeri 3 Kendari. Kendari: Institut Agama Islam Negeri Kendari.

Khausar.2014. Pengaruh Penerapan Metode Pembelajaran Guru Yang Bervariasi Terhadap Peningkatan Hasil Belajar Pada Siswa Kelas XI SMA Negeri 1 LabuhanHaji Timur Aceh Selatan. Aceh: STKIP. Bina Bangsa Meulaboh.

Logitapraja Harsep Sian. 2017. Pengaruh Konflik Peran, Stres Dan Lingkungan Kerja Terhadap Kinerja Guru Di SMKN Ihya' Ulumudin Singojuruh. Jember: STIE. Mandala Jember.

Novauli,Feralys. 2012. Pengaruh Kompetensi Guru Terhadap Peningkatan Prestasi Belajar Pada SMP Negeri Di Kota Banda Aceh. Banda Aceh: SMP Negeri 3 Banda Aceh.

Pratama, Didik, Lutfi. 2013. Pengaruh Kompetensi Guru Dalam Mengajar Dan Motivasi Belajar Siswa Terhadap Prestasi Belajar Siswa Kompetensi Dasar Melakukan Prosedur Pengadaan Peralatan Kantor Kelas X SMK Negeri 1 Purwodadi Tahun 2011/2012. Semarang: Universitas Negeri Semarang.

Suradi. 2002. Faktor-Faktor Kualitas Pelayanan Pengaruhnya Terhadap Kepuasan Pelanggan Bank Umum Di Wilayah Kerja Bank Indonesia Surabaya. Surabaya; Universitas Negeri 17 Agustus 1945 Surabaya.

Sugiharsono. Sutardi. 2016. Pengaruh Kompetensi Guru, Motivasi Belajar, Dan Lingkungan Keluarga Terhadap Hasil Belajar Mata Pelajaran Ekonomi. Yogyakarta: Universitas Negeri Yogyakarta.

Tsauri Sofyan. 2003. Faktor-Faktor Yang Mempengaruhi Kinerja Dosen Di Sekolah Tinggi Agama Islam Negeri (STAIN). Jember: STIE. Mandala Jember.

Wiyanti Erni.2017. Pengaruh Model Pembelajaran Kooperatif Tipe Group Investigation Dan Motivasi Siswa Terhadap Prestasi Belajar Fisika (Studi di SMAN 1 Pesanggaran-Banyuwangi. Jember: STIE. Mandala Jember. 